\title{
Ghanaian Banking Crisis of 2017-2019 and Related Party Transactions
}

\section{Anthony Q. Q. Aboagye}

Department of Finance

University of Ghana Business School

\section{Correspondence:}

aaboagye@ug.edu.gh

qaboagye@gmail.com

$+233-24-425-2596$ https://dx.doi.org/10.4314/ajmr. v27i1.1

\begin{abstract}
Early in 2017, a new management team took over the helm of affairs at the central bank of Ghana. Preliminary evidence available to them suggested that a number of banks were distressed. Further investigation by them revealed that poor corporate governance, false financial reporting, and insider dealings were major contributory factors to the poor state of affairs that they found. The central bank then engaged the banks in question to try to rectify the situation. Unfortunately, things did not work out. Subsequently, over the course of sixteen-months, the banking licenses of nine banks out of 35 were withdrawn. This paper focuses on the role insider and related party transactions (RPTs) played in what has been referred to as Ghana's banking crisis and presents details of the extent to which affected banks engaged in RPTs, possibly in a quest to seek rents. Content analysis of the central banks allegations against affected banks suggests that being members of conglomerate groups pre-disposed banks to rentseeking related party transactions. To forestall such activities, it is recommended that banks should not be allowed to belong to conglomerate groups. Also, entities with controlling interests in non-regulated firms should not be allowed to gain controlling interests in banks. Further, the central bank should be extra vigilant in carrying out its risk-based supervisory responsibilities. Finally, Ghana should consider adopting the twin peaks approach to regulating her financial system.
\end{abstract}

\section{Introduction}

In 2015, the central bank of Ghana, called the Bank of Ghana, undertook an exercise to review the quality of the assets of banks. It produced a report titled, The Asset Quality Review (AQR) of Banks. The Bank of Ghana updated the 2015 report with 2016 data. The reports pointed to 10 banks being undercapitalized. Subsequently, the central bank engaged the banks in question to try to address concerns unearthed by the 
2015 and 2016 reports. On January 4, 2019, the Governor of the central bank declared:

... In short, the financial system bad reached a tipping point and we could not have assumed business as usual. The Bank of Ghana, therefore, embarked on a comprehensive reform agenda, with the objective of cleaning up the sector and strengthening the regulatory and supervisory framework for a more resilient banking sector.

... Ladies and gentlemen, it has been an eventful last twenty months during which the Bank of Ghana has had to take tough but necessary bold steps to clean up the banking sector and to reposition it to support the economic growth and transformation agenda for Ghana.

Here is a summary of the outcomes of the engagements and decisions taken over period 2017-2019.

\section{The Case Against Affected Banks}

Following are the summaries of the matters raised by the Bank of Ghana against the 10 banks for which their banking licenses were withdrawn.

\section{UT Bank Limited and Capital Bank Limited}

On August 14, 2017, the Bank of Ghana revoked the banking licenses of UT Bank Limited and Capital Bank Limited on account of "severe impairment" of their equity capital. The central bank approved a "Purchase and Assumption transaction" that transferred all deposits and selected assets of UT Bank and Capital Bank to GCB Bank Limited.

At the Annual Dinner of the Chartered Institute of Bankers Ghana on December 2, 2017, the Governor of the Bank of
Ghana gave insight into specific offences that led to the revocation of the banking licenses of the two banks. The reasons include, Graphic Online (2017):

- non-separation of the activities of the banks from those of their holding companies;

- excessively high executive compensation schemes which were out of tune with the results the banks were achieving;

- acceptance of gifts from the bank by non-executive directors of the banks which compromised their independence and their ability to perform their fiduciary duties as checks on executive directors;

- some non-executive members of the boards of directors of the two banks had put themselves in conflict of interest situations by acting as consultants to the banks on whose boards they sat;

- the banks did not adhere to credit management principles and procedures. The banks were heavily exposed to insiders and related parties with no evidence that interest was being paid on those loans;

- funds of the banks were diverted to holding companies of the conglomerate groups to which they belonged leading to illiquidity;

- board meetings were irregular resulting in weak board oversight; and

- the banks borrowed heavily from high net worth individuals at very high cost.

\section{uniBank (Ghana) Limited}

On 20th March 2018, the Bank of Ghana (BoG) appointed KPMG Ghana as Official Administrator of uniBank 
(Ghana) Limited, effective that date, KPMG was to run all aspects of the business of the bank and in the process ascertain the true financial condition of the bank.

Some four months later, BoG declared that effective August 1, 2018, it was revoking the banking license of uniBank based on the report BoG had received from the Official Administrator who had concluded that uniBank was insolvent and that its operations were unsustainable. Providing evidence, the Administrator indicated that it had concluded that:

- uniBank's interest income and other income were less than the bank's cost of funds (loans and other liabilities) and its overhead expenses;

- the bank's loan portfolio was nonperforming;

- the bank's internal control systems were weak. Significant deficiencies existed in credit underwriting, loan approval, compliance and reporting processes;

- significant deficiencies also existed in the bank's corporate governance, risk management, compliance and management;

- unlawful transactions involving shareholders and related parties were engaged in.

\section{Royal Bank Limited}

On the same date, August 1, 2018, the banking license of The Royal Bank Limited was also withdrawn on grounds that it was insolvent and faced acute liquidity challenges. The bank's insolvency was attributed to:

- under-provisioning for loans;

- over estimation of investment assets;
- rejection by the central bank of certain fixed assets presented by The Royal Bank for capital purposes;

- non-performing loans - $78.9 \%$ of total loans were non-performing;

- poor credit risk management;

- poor liquidity risk management; and

- weak corporate governance systems.

The BoG also said the capital position of the bank had been overstated in order to create appearance of compliance with capital adequacy laws. Citing other wrongdoing, the central bank said transactions worth USD 33 million (GHS161.92 million) were entered into with shareholders and related and connected parties and were structured to circumvent rules that limit exposure to individual entities.

\section{The Beige Bank Limited}

Another affected bank was The Beige Bank Limited. The BoG's August 1, 2018 statement declared that a special examination it conducted into the affairs of the bank six months after the bank commenced operations in December 2017 revealed that the bank was insolvent. The bank's capital adequacy ratio was negative $17.18 \%$, against the legal minimum of positive $10 \%$.

The following infractions were documented:

- the supposed additional financial injection into the bank by its parent company soon after the bank received its temporary license were Beige Bank's own funds that an affiliate company of Beige Bank had sourced from Beige Bank and passed these on to their parent in violation of the law. The amount 
involved was Beige Bank's USD 33.5 million (GHS 163.47 million) that it had placed as investment with an affiliate company that was an asset management company;

- the bank had "persistently breached the cash reserve requirement of 10\%" since January 2018;

- $72.8 \%$ of the bank's loan portfolio was non-performing.

\section{Sovereign Bank Limited}

The BoG's August 1, 2018 statement indicated that this bank's capital had been wiped out (insolvent) on account of the following:

- funds provided as initial capital of the Sovereign bank by its founding shareholders in January 2016 did not belong to them. The BoG traced these funds back to Capital Bank Limited, whose licensed had been revoked a year earlier. After presenting these funds to obtain its banking license, Sovereign bank then placed a chunk of its capital with another financial institution as investment in that financial institution. Investigations showed that these investments were subsequently liquidated by the shareholders of Sovereign bank and parties related to them;

- the bank's loan portfolio was nonperforming;

- the bank had become illiquid by August 1,2018; and

- the bank was guilty of persistent breaches of key regulatory requirements and prudential limits.

\section{Construction Bank Limited}

The August 1, 2018 statement also announced withdrawal of the banking license of Construction Bank Limited.
Construction Bank was licensed in May 2017. The Bank of Ghana reported that, while it was working with KPMG as the Official Administrator of uniBank, the BoG discovered the following:

- the initial minimum paid-up capital provided by the promoter/shareholder of Construction Bank was made up of a USD 7 million (GHS 34 million) loan obtained from NIB Bank Limited and another to the tune of USD 12.5 million (GHS 61 million) obtained from uniBank in contravention of Act 930;

- Construction Bank could not access USD 16.4 million (GHS 80 million) out of the amount the bank reported as its paid-up capital which it had invested with both NIB Bank Limited and uniBank;

- the bank could not inject additional funds to restore its minimum capital to the required USD 25 million (GHS 120 million). This inability threatened the safety of depositors' funds and the stability of the banking system;

- the promoter/shareholder could also not submit a credible plan for recapitalizing the bank's capital to the required minimum at the time of its licensing.

\section{Premium Bank Limited}

On January 4, 2019, the BoG announced revocation of the banking license of Premium Bank Limited. Premium Bank had become insolvent effective November 30, 2018, with a capital adequacy ratio of negative $125.26 \%$, BoG announced. The following infractions were reported:

- BoG investigations revealed that initial funds contributed by shareholders as capital were borrowed 
funds, which loan was repaid soon after the bank received its banking license, hence the capital was not available for Premium Bank to work with;

- as at November 2018, 37.2\% of the bank's loans, had been granted to related parties. These loans were more than the bank's equity, which is in breach of the regulatory limit of $10 \%$ of equity;

- outstanding loans to related parties were wrongly classified by the bank as "investments";

- the bank had also submitted inaccurate prudential returns to the central bank;

- finally, the bank could not post the new minimum required capital of USD 80 million (GHS 400 million) that was required of universal banks by January 1, 2019.

\section{Heritage Bank}

On January 4, 2019, the central bank also announced revocation of the banking license of Heritage Bank Ghana Limited (which was issued to it on October 4, 2016) on grounds that:

- it had obtained its banking license on the basis of capital with questionable sources. Section 9 (d) of the Banks and Specialised Deposit-Taking Institutions Act, 2016 (Act 930) and Section 1 of the Anti-Money Laundering Act of 2008 (Act 749) require acceptable capital to be obtained from lawful and transparent sources;

- it was unable to meet the new minimum capital requirement (USD 80 million) that became effective January 1, 2019;

- the main shareholder of the bank did not meet the "fit and proper" test for owning a bank.

\section{GNBank Limited}

The January 4, 2019 statement also dealt with the case of GN Bank Limited. GN Bank was unable to meet the new minimum capital of USD 80 million that became effective January 1, 2019. As a result, it applied for, and was approved for a license to operate as a savings and loans company to be called GN Savings and Loans, (lower capital requirement) and was given time to strip itself off businesses not compatible with a savings and loans company and to inject additional capital. It had up to June 30, 2019 to do this.

On August 16, 2019, the Bank of Ghana revoked the savings and loans license of GN Bank on the grounds of not meeting key prudential regulatory requirements (consistent with its new status) and that GN was insolvent.

Among other causes, the central bank traced GN's insolvency problems to

- overdraft and other credit facilities it had extended to its related parties under circumstances that violated relevant prudential rules;

- these related parties were not able to honour their obligations to GN Savings and Loans.

\section{Common Trends}

Ultimately, the banking licenses were revoked because shareholders did not have the minimum capital that was required to operate as universal banks. Of the ten banks discussed above, only two, Construction Bank and Heritage Bank, were not accused directly of undertaking illegal "related party transactions", "con- 
nected parties transactions", transactions involving "shareholders", "parent companies" or "affiliate companies". Taking a cue from this observation as some indication that unwholesome related party transactions may be rife in the industry, this study presents an overview of this concept in the literature, then provides international evidence of related party transactions that amounted to rentseeking behaviour. It then does a content analysis of BoG statements to highlight the extent to which affected banks fell foul of good bank management practices. Findings of content analysis are then discussed in the context of the literature on avoiding or reducing rent-seeking behavior by financial institutions and ends with concluding remarks on financial regulation in Ghana.

\section{Literature Review Conglomerates and Related Party Transactions}

A business conglomerate is a collection of businesses in unrelated businesses controlled by one company. A financial conglomerate is one whose members are all financial services providers and hence are regulated by one regulator or the other. Conglomerates in the United States or other Western countries consist of a single holding company with multiple subsidiaries engaged in different businesses. In Japan, the keiretsu model is analysed as a conglomerate. It is a loosely organized alliance of businesses that extends to the social life of Japanese. Alliance members own portions of the shares of other members. The alliance is formed around a core bank. Chinese conglomerates tend to be state-owned enterprises, while South Korean conglomerates, called chaebol, are owned and operated by families. Well known conglomerates exist in Indian too. They include the Tata Group and the Mahindra Group.

The literature (see for example, Kawai, 2009) notes that conglomerate membership, especially as obtains in Japan, helps insulate members from stock market fluctuations and takeover attempts, and enhances plans to work on long-term projects. Such a system also helps lower transaction costs such as coordinating costs, searching costs and switching costs. It also helps reduce the risk that counter parties may not abide by contracts, and helps in testing of product quality under non-market conditions. Another often touted advantage of membership of a conglomerate is that some members may provide capital (or other funds or services) to other members below market rates. In situations where external capital markets are not developed enough, internal capital allocation by members of the conglomerate to other members can be an effective way for cash needy members of conglomerates to access capital, it is argued. It should however be noted that finance theory preaches optimal allocation of resources. Allocation to "friends and family" may not be optimal.

It is also argued that, for the firm controlling the conglomerate, diversification of its investments into many conglomerate members results in reduction of unsystematic risk. This advantage is often enhanced if the group is made up of entities with different business cycles.

Here too, finance theory notes that investors interested in holding diversified portfolios should not focus on holding companies. Investors may be better off con- 
structing their own diversified portfolios by buying shares of standalone companies that operate in the lines of business of members of the conglomerate of interest on the following grounds. For one thing, beyond the management of the individual members of the conglomerate, existence of the controlling entity translates to another layer of management, which increases cost over and above what an equivalent standalone firm would bear, all things equal. Another disadvantage is difficulty in assessing the performance of individual members of the conglomerate. Accounting disclosures made at the group level may be less informative for analysis since accounting data are grouped. As a result, the true picture of individual performance may not emerge.

Akerlof and Romer (1993) noted that efficient financial markets, noting these disadvantages, mark down the value of conglomerates relative to a portfolio of standalone firms. Thus, conglomerates are often worth less than the sum of their parts in efficient markets. Also, lack of equal focus on all members of a conglomerate at the parent holding company level, and possible lack of capacity to manage unrelated businesses equally well is another disadvantage of conglomerates. Another disadvantage is potential culture clashes between different members of the conglomerates that can destroy value. Still another is inertia or waiting for the right signals from parents, which can interfere with development of innovation at the affiliate.

\section{Related Parties and Rent-Seeking Behaviour}

In speaking about conglomerates, finance literature uses the term related parties frequently.
International Financial Reporting Standards (IFRS, 2020) refers to related parties as:

a) A person or a close member of that person's family is related to a reporting entity if that person has control, joint control, or significant influence over the entity or is a member of its key management personnel; or

b) An entity is related to a reporting entity if, among other circumstances, it is a parent, subsidiary, fellow subsidiary, associate, or joint venture of the reporting entity, or it is controlled, jointly controlled, or significantly influenced or managed by a person who is a related party.

IFRS defines related party transaction

... as a transfer of economic resources or obligations between related parties, or the provision of services by one party to a related party, regardless of whether any consideration is exchanged. The parties to the transaction are related prior to the transaction.

To explain why related party transactions and conglomerate/affiliate transactions can be problematic, we turn to the literature on rent-seeking behavior.

\section{Rent-Seeking}

The term rent-seeking too has been given a number of definitions in the literature. Corporate Finance Institute (2015) defines the phrase as, an individual or an entity seeking to increase their own wealth without creating any benefits or wealth to the society. Fischer (2005) says, Rent-seeking describes the ability to capture incomes without producing output or making a productive contribution.

In the main, rent-seeking activities are geared at obtaining financial gains or other benefits by influencing distribution, rather 
than production, of economic resources. For example, a conglomerate holding company may use its own equity as seed money to establish a number of independently incorporated subsidiaries, then find ways to attract others to become equity holders in these subsidiaries, which subsidiary may then borrow funds. Properly structured, the holding company would now be controlling much larger subsidiaries than its own equity could have established. That is not all. The holding company may then encourage transfer pricing among subsidiaries. Being itself located in a low tax jurisdiction, it gets to keep much of the profits of the conglomerate group. This would amount to rentseeking behaviour.

Fischer (2005) argues that rent-seeking discourages innovation in revenue enhancement, cost reduction, technology improvement, etc. and instead relies on "connections" for redistribution of economic resources to the firm for increase in wealth. And continues that, such practices result in reduction in overall economic efficiency. Rent-seeking behaviour results in loss of government revenues, decrease in competition and rise in income inequality. Sorkin (2009) argues that, the too-bigto-fail syndrome is a rent-seeking attitude, and was one reason why many large United States financial institutions took on excessive risks that resulted in the 2007-2009 global financial crisis.

\section{Related Parties in Banking}

Two views on related party transactions (RPT) have emerged in the banking literature. One view, often called information view of RPTs, hypothesizes that close relationships between banks and customers, especially borrowers makes for close monitoring of customers (and monitoring of insiders by insiders), reduces risk and facilitates the flow of funds among group members, especially when cost of information is high and contract enforcement costs are also high. See for example, Lamoreaux (1994).

The alternate view of RPT is the looting view (also called tunneling view). It hypothesizes that close relationship between banks and borrowers allows insiders to divert resources from depositors or minority shareholders to insiders, (Akerlof and Romer, 1993, Johnson et al. 2000). Morck and Nakamura (1999) and Kang and Stulz (1997) hypothesize this view as a benefit of keiretsu groups in Japan.

Explaining how the looting works, proponents argue that when a banking system has deposit insurance, managers of banks can take excessive risk or make loans to their own companies on softer than market terms and suffer little or no consequences if these loans fail. Alternatively, even if the banking system did not have deposit insurance, bank managers have incentive to divert bank funds by making loans on softer than market terms to firms in which their share of earnings is greater than their share of profits in the bank. Akerlof and Romer (1993) showed that looting is likely when it is anticipated that the future prospects of gaining from the company are less than what the owners can loot now. They further note that during periods of financial distress, bank insiders use their control over lending policies to loot banks. That is, siphon out bank resources by making loans that the banks credit policy would not ordinarily support. 
However, these days in Europe and the United States, conglomerates are increasingly being viewed as heavy-footed, unfocused, and inefficient and are losing their shine with investors. For example, General Electric of the US was dropped from the Dow Jones Industrial Average in 2018 because of falling value (having been weighed down, in part, by losses at its financial services unit).

Tripathi et al. (2019) however, believe that in emerging markets with weak competition and scarce capital, conglomerates which have a sharper focus and a welldefined strategic identity are well placed to be profitable. Challenges they face these days include gradual opening of their home markets to foreign investors resulting in increased competition. Also, capital is becoming more available in developing countries for standalone local firms to access, hence they too add to the competition that conglomerates now face.

\section{International Evidence on Rent-Seeking and Related Party Transactions}

La Porta et al. (2003) state that, in the main, rent-seeking is more prevalent in environments in which institutions are weak, which is typical of developing economies. However, they emphasize that rent-seeking does exist in developed economies too. For example, when lobbyists in the United States lobby governments to tilt financial rules in their favour, they are rent-seeking.

Schwab and Werker (2018) argue that in manufacturing, rent-seeking lowers productivity growth especially in poor countries with weak institutions. Overall, they conclude that rent-seeking is not good for business. Here are some country studies.

\section{India}

Bertrand et al. (2002) provide evidence of significant funneling (tunneling) of resources into and out of Indian business conglomerates. Controlling interests funnel out resources from businesses in which their share of profits is lower to businesses in which their share of profits is higher. Fewer resources are funneled out of family-owned conglomerates than non-family owned conglomerates. They argued that stock markets incorporate expectation of the impact funneling of resources into or out of members of a conglomerate when they value them. Firms that are at the receiving end of funneling of conglomerate resources are valued more. The same holds for those from whom less funds are tunneled away.

\section{Mexico}

La Porta et al. (2003) provide evidence that "supports the view that in some important settings related lending is a manifestation of looting" in Mexico. A study of 17 banks in the mid 1990s revealed that $20 \%$ of commercial lending by the banks is to related parties and that related party lending takes place on better terms than arm's-length lending (annual interest rates are 4 percentage points lower); related party loans are 33 percent more likely to default; and recovery rates on defaulted related party loans are 30 percent less than loans to unrelated parties.

\section{Pakistan}

Khwaja and Mian (2005) estimated that for Pakistan, between 1996 and 2003, politically connected agents had more access to credit from government banks at lower cost than firms without political connec- 
tions. They also estimated economy-wide costs of rents to be 0.3 to 1.9 percent of GDP annually over the period.

\section{Argentina}

Hertzberg at al. (2010) found that among Argentinian banks, rotation of loan officers improved the accuracy of reports that loan officers wrote because such officers would rather they reported the true situation of a loan themselves than for that to be exposed by a succeeding loan officer.

Khwaja and Mian, (2011) argue that lack of more effort to report more accurately the true status of a loan in the absence of rotation amounts to rent-seeking because such officers do not directly bear the cost of bad loans.

\section{Jamaica}

For Jamaica, Tennant (2013) finds evidence that "looting and informationbased motivations distinctly and separately impact" related party transactions. Related party loans are influenced heavily by motivations to loot, while investments in related parties are influenced by information efficiencies (making the most use of limited information).

\section{Bank Regulation in Ghana and Related Banking}

The Bank of Ghana Act 2002, (Act 612) and Bank of Ghana (Amendment) Act, 2016 (Act 918) establish the Bank of Ghana as the central bank of Ghana and gives it overall supervisory and regulatory authority in all matters relating to banking in order to achieve a "sound, efficient banking system in the interest of depositors and other customers" and of the whole economy.

The Banks and Specialised Deposit-Taking Institutions Act, 2016 (Act 930) is the pri- mary law that governs commercial banking in Ghana. It regulates institutions which take deposits and grant loans. Act 930 gives the Bank of Ghana authority to issue periodic Bank of Ghana Notices/Directives/Circulars/Regulations to banks and other entities it regulates.

The Bank of Ghana's (2018) definition of related party in respect of entities it regulates states that related party in relation to business transactions means a company/ entity in which

a) The Regulated Financial Institution or any of its Directors or Key Management Personnel have equity interest of at least $5 \%$;

b) $A$ director(s) of the Regulated Financial Institution also serves as a director(s) of the company / entity;

c) A director or Key Management Personnel of the Regulated Financial Institution has influence in the company/entity.

Bank of Ghana's (2018) directive to regulated financial institutions in respect of related parties states that

The Board shall ensure that
transactions with related parties
(including internal group transactions)
are reviewed to assess risk and are
subject to appropriate restrictions (e.g.,
by requiring that such transactions be
conducted on non-preferential
terms/basis) and applicable legislation
and other requirements such as those
prescribed under sections 67 to 70 of
Act 930 regarding exposure limits for
loans to relatedparties and staff.

The Board shall ensure that transactions with related parties (including internal group transactions) are reviewed to assess riske and are subject to appropriate restrictions (e.g., by requiring that such transactions be conducted on non-preferential terms/basis) and applicable legislation and other requirements such as those prescribed under sections 67 to 70 of loans to related parties and staff. 


\section{Relevant Provisions in Act 930}

The Act contains elaborate provisions on the regulation of what the Act calls corporate conglomerates. Two sections are worthy of note.

\section{Ownershipand Control}

- Section 42 envisages that a bank or specialised deposit-taking institution may be a member of a corporate group;

- Section 43 envisages that [corporatel persons must register as financial holding companies (presumably as head of a corporate group) and receive approval before functioning as such;

- Section 46 details activities that financial holding companies may or may not engage in;

- Section 47 speaks to the power of the Bank of Ghana to require restructuring of ownership or structure of the conglomerate. For example, if the Bank of Ghana determines that current ownership/ structures hinders effective supervision of the regulated entity; and

- Section 48 speaks to conditions under which withdrawal of registration as a financial holding company by Bank of Ghana may be effected.

\section{Restrictions on Lending and}

\section{Investments}

- Sections 61, 62, 63, 64, 65, 66 impose limits on financial exposure and dealings with affiliates;

- Sections 67, 68, 69, 70, 71, 72 put restrictions on financial exposures to insiders, related parties and staff;

- Section 73 limits investment by banks or specialised deposit-taking institutions in respect of non-subsi- diary institutions;

- Section 102 speaks to remedial measures that the Bank of Ghana may take against banks, specialised deposit-taking institutions or financial holding companies that flout provisions in the Act;

- Section 103 speaks to remedial measures that the Bank of Ghana may take against relevant persons (directors, key management personnel, and significant shareholders) that flout provisions in the Act.

This literature review is the background against which this paper assesses the role of related party transactions in the recent banking crisis in Ghana.

\section{Methodology}

The methodology adopted in this investigation is content analysis of statements put out by the Bank of Ghana (BoG). The intent is to ascertain the extent to which certain patterns of behaviour identified by BoG was common to banks that failed. Reading through the case made against each bank by the central bank, phrases like related party transactions, inadequate capital, non-performing loan portfolios, etc., re-occur again and again.

Content analysis is justified on grounds that banks are opaque, however, BoG is in a privileged position that gives it insight into operations of banks it supervises, which the BoG communicated to the Ghanaian public when it withdrew licenses of affected banks. In addition, the infractions that the banks were said to have committed were made openly by BoG, and in fact, a number of the banks have been hauled to court. Taken together, these provide external validity to use of 
content analysis.

This study quantifies the occurrence of certain words and phrases used by BoG (conceptual analysis). Thus, the researcher has no influence on the results and the subjects (banks) are not now required to behave or act in one way or the other. Implementation of conceptual analysis is at relatively low cost (researcher's time only) beyond cost of assessing BoG releases.

The contents to be analysed are $\mathrm{BoG}$ statements issued between August 2017 and January 2019, plus another statement issued in August 2019. Keywords used in assessing bank performance in the banking literature are the themes around which conceptual analysis is conducted. At the end, a tally of how often each pertinent word or phrase is used in explaining withdrawal of licenses of all ten banks is counted.

\section{Findings and Discussions}

Findings of the study are first presented, then discussed.

\section{Findings}

In carefully reading the statements issued by $B o G$, one identifies a number of explicit phrases used in assessing bank performance. Slight variations exist in the wording of some of the phrases, but largely the meanings of the phrases are preserved. The BoG makes it abundantly clear that banking licenses were withdrawn because the capital (shareholders' funds) of the banks had become inadequate or impaired to the point that the banks had become insolvent following infractions they committed against the terms under which banking licensing were issued to them.

The BoG cited the infractions listed in Table 1.

Table 1: List of infractions

\begin{tabular}{ll}
\hline Infraction & Details of infraction \\
\hline (a) & The banks were members of conglomerates and engaged in illegal related \\
& party transactions \\
(b) & Non-executive board members failed to carry out their fiduciary duties as \\
& checks on executive directors \\
(c) & Non-executive board members put themselves in conflict of interest \\
(d) & Dituation \\
(e) & Problems with loan portfolio (non-performing) \\
(f) & Weak corporate governance and weak board oversight of banking \\
(g) & Procedures \\
(h) & Other breaches of provisions of Act 930, (typically unacceptable sources \\
& Illiquid/breach of cash reserve requirement \\
\hline
\end{tabular}


Table 2 documents infractions committed by each bank. It says that the most frequent infraction is infraction (a) membership of conglomerates and illegal related party transactions. This infraction was committed by eight out of the 10 banks $(80 \%)$. Only two out of the 10 affected banks were not guilty of this.

Following illegal related party transactions, the category Other breaches of provisions in the Banking Act 930 was next most frequent violation. 60 percent of affected banks were guilty of this infraction. As pointed out above, relevant provisions of Ghana's Banking Act 930 are sections 61, 62, 63, 64, 65 and 66, which impose limits on financial exposure and dealings with affiliates, as well as sections $67,68,69,70,71$ and 72 of the Act which put restrictions on financial exposures to insiders and related parties.

Five out of the ten banks were found guilty of committing Disregard for BoG credit guidelines and/or bank's own credit procedures; Problems with loan portfolio (non-performing); and Illiquid/ breach of cash reserve requirement.

Table 2: Content analysis of central bank's report on infractions

\begin{tabular}{lllllllll}
\hline Bank & \multicolumn{7}{c}{ Infraction } \\
\hline (a) & (a) & (b) & (c) & (d) & (e) & (f) & (g) & (h) \\
\hline UT Bank \& & $\sqrt{ }$ & $\sqrt{ }$ & $\sqrt{ }$ & $\sqrt{ }$ & $\sqrt{ }$ & $\sqrt{ }$ & $\sqrt{ }$ & $\sqrt{ }$ \\
Capital Bank & $\sqrt{ }$ & $\sqrt{ }$ & $\sqrt{ }$ & $\sqrt{ }$ & $\sqrt{ }$ & $\sqrt{ }$ & $\sqrt{ }$ & $\sqrt{ }$ \\
uniBank & $\sqrt{ }$ & $\sqrt{ }$ & & $\sqrt{ }$ & & $\sqrt{ }$ & $\sqrt{ }$ & \\
Royal Bank & $\sqrt{ }$ & & & $\sqrt{ }$ & $\sqrt{ }$ & $\sqrt{ }$ & & $\sqrt{ }$ \\
Beige Bank & $\sqrt{ }$ & & & $\sqrt{ }$ & $\sqrt{ }$ & & & $\sqrt{ }$ \\
Sovereign Bank & $\sqrt{ }$ & & & & $\sqrt{ }$ & & $\sqrt{ }$ & $\sqrt{ }$ \\
Construction Bank & & & & & & & $\sqrt{ }$ & \\
Premium Bank & $\sqrt{ }$ & & & & & & $\sqrt{ }$ & \\
Heritage Bank & & & & & & & $\sqrt{ }$ & \\
GN Bank & $\sqrt{ }$ & & & & & & $\sqrt{ }$ & \\
\hline Total banks & 8 & 3 & 2 & 5 & 5 & 4 & 6 & 5 \\
\hline
\end{tabular}

\section{Details of related parties of affected banks}

UT Bank Limited, (Graphic Online, 2017).

UT Bank was a subsidiary of UT Holdings Limited, which owned the following subsidiaries in addition:

1. UT Bank Limited

2. UT Logistics Limited (provision of logistical services);

3. UT Properties Limited (real estate development and management);

4. UT Collections Limited (debt recovery);

5. UT Private Security Limited (armed and unarmed private security service);

6. Gateway Wealth Management 
Limited;

7. UT Life Insurance Company Limited (life insurance);

8. UT Financial Services Nigeria Limited (loans and lease financing so-lutions);

9. UT Financial Services South Africa Limited (savings and loans).

\section{Capital Bank Limited}

The founder of Capital Bank is also said to own many other businesses. They include:

1. Ocean Spring Mineral Water Limited;

2. Breitling Services Limited;

3. Gye Nyame Realty Lmited;

4. Capital and More Co. Limited;

5. Accent Financial Services Limited;

6. Life Assurance Limited; and

7. Capital Africa Group Limited.

The founder was also said to have business interests in the following:

8. Nordea Capital Limited;

9. Commerz Savings and Loans Limited;

10. Sovereign Bank Limited (now defunct);

11. Essien Swiss International Capital Holdings Limited (ESICH);

12. First Capital Plus LLC (Zimbabwe);

13. Gye Nyame Resources LLC (Zimbabwe); and

14. Bill Minerals LLC (Zimbabwe).

Beige Bank Limited

The Beige Bank is a member of The Beige Group Limited, the holding company which has four subsidiaries which provide financial services, namely,

1. The Beige Bank (banking);

2. Legacy Pensions Trust Limited (pensions management);

3. Beige Assure/Unique Life Insurance (life insurance); and

4. Beige Capital Asset Management
Limited (investments management).

uniBank Ghana Limited

uniBank is a member of a group of conglomerate companies which are subsidiaries of House of Duffuor Assets (HODA) Holdings Limited. The conglomerate consists of more than 30 businesses in banking, insurance, real estate and media. Before it went under, uniBank was the most valued member of the stable.

Here is the list of members of the conglomerate:

Banking:

1. uniBank Ghana Limited;

Savings \& Loans:

2. uniCredit;

Insurance:

3. Star Assurance Company Limited (non-life);

4. StarLife Assurance Company Limited (life insurance);

5. Star Microinsurance Services Limited

6. Anchor Insurance Brokers Limited

7. Crown Insurance Brokers Limited;

8. Shield Insurance Brokers

Media business:

9. EIB Network Limited

10. EIB Network: AGOO TV

11. EIB Network: KASAPA FM

12. EIB Network: LIVE FM

13. EIB Network: STARR FM

14. EIB Network: COOL FM

15. EIB Network: ABUSUA FM

16. GH One (television)

Fund Management.

17. uniSecurities 
Others:

18. Topp Core Security Ghana Limited

19. Uniprecision Printing Press Limited

20. Duffuor Foundation

21. Daily Heritage

22. Institute of Fiscal Studies (thinktank and consultancy)

\section{GN Bank Limited}

The holding company of the conglomerate to which GN Bank belonged is Groupe Nduom. Groupe Nduom owns many subsidiaries who are into different businesses in and outside of Ghana.

In Ghana, the subsidiaries include:

1. GN Reinsurance Company Limited

2. GN Savings/Bank

3. GN Life Assurance Company Limited

4. Bedrock Insurance Ltd

5. Groupe Nduom Ltd

6. Qualtek Co. Ltd

7. Fresh Pak Co. Ltd

8. GN Power Co. Ltd

9. Endela Africa

10. GN Concrete Ltd

11. GN Quarry Ltd

12. GN Printing Ltd

13. GN Electronics

14. GN Logistics

15. GN Farms

16. Yorke Properties Ltd

17. Sterling Protection Services Ltd

18. EPPL Co. Ltd

19. Digicut And Advertising Co. Ltd

20. Pentrust Co. Ltd

21. Gold Coast Brokerage Ltd

22. Gold Coast Holdings Ltd

23. Gold Coast Advisors Ltd

24. Gold Coast Fund Mgt Ltd

25. Monica Yorke School

26. Nduom School of Business \& Technology

27. ATV Broadcasting
28. GN TV

29. Ocean One TV

30. Sunshine FM

31. Suhupieli FM

32. Kasapreko FM

33. Hejorle FM

34. Good Life FM

35. Ezzy FM

36. Enigye FM

37. Pupeelum FM

38. Puopel FM

39. Sikapa FM

40. Okyeaman FM

41. Adwenpa FM

42. Today Newspaper

43. Coconut Grove Hotels Ltd

44. Elmina Sharks FC

45. Sea Lion FC

46. Gold Coast Fund Management

Other subsidiaries exist in

47. Togo

48. Ivory coast

49. Liberia

50. United Kingdom, and

51. United States

Clearly, the Groupe Nduom is a huge conglomerate. Co-ordinating and controlling such a vast empire of business is bound to be no mean challenge.

\section{Premium Bank Limited}

Premium Bank was owed by the Vanguard Group Limited. Aside that, the central bank mentions Capital Bank and the Royal Bank as entities with which Premium Bank engaged in illegal related parties' transactions.

The Royal Bank Limited

The Royal Bank too was accused of having engaged in illegal transactions with shareholders, related and connected parties. 


\section{Sovereign Bank}

The Sovereign Bank is said to be connected with owners of collapsed Capital Bank.

\section{Discussion}

The Joint Forum on Financial Conglomerates (1999) cautions supervisors of regulated entities which are members of conglomerates to be wary of the following risks as they do their work:

- conglomerate contagion: a situation in which if a member or some members of a conglomerate are experiencing financial difficulties, other members of the conglomerate may be perceived as having the potential to suffer the same fate simply because of common membership of a conglomerate group;

- intra-group exposures: direct and/or indirect claims which entities within conglomerates make on each other;

- conflicts of interest. for example, the decision by a bank member of a group to lend to another member may be influenced by group membership;

- fit and proper tests: managers of regulated entities may pass the fit and proper tests, but within a conglomerate setting, managers of the controlling firm of the conglomerate, who are superiors of managers of regulated financial firm and who do not need to undergo the fit and proper test, may exercise open or subtle control over many decisions (including risk taking) of the regulated firm's business or, override decisions of managers of the regulated institution who would have passed the fit and proper test; and

- supervisory arbitrage: in jurisdictions in which financial services are regulated and supervised in silos, a financial conglomerate member whose business does not fit neatly under any of the regulators, may opt to be regulated by a supervisor thought to be less strict or try to avoid regulation all together. Readers familiar with the Ghanaian situation may recall that in Ghana during the banking crisis, one entity, called MENSGOLD, tried to play this game.

The heart of the matter is that supervisory rules and practices that are enacted to apply to regulated financial institutions or standalone financial institutions cannot be extended to members of conglomerate who are not prudentially regulated. Even for financial conglomerates, whose members are all prudentially regulated, challenges exist in respect of overall coordination of supervision by different regulatory agencies. Following lessons learnt from the global financial crisis of 2007 - 2009, The Joint Forum (2011) published supplementary framework for the supervision of financial conglomerates as supplementary to their 1999 framework.

Together, the principles underlying the frameworks provide that there must be a supervisor for each financial conglomerate whose responsibilities should be group-level supervision and coordination of any other regulators that may be involved in regulating other members of the conglomerate. Secondly, there must be laid out a clear and transparent process for effective group-level supervision that identifies roles and responsibilities of regulators. Finally, there must be spelt out effective mechanism for resolving dif- 
ferences that may arise among supervisors of conglomerates.

\section{Concluding Remarks}

There is consensus in the literature that efficient intermediation of financial services by financial intermediaries such as banks do, support the growth of economies. Unfortunately, financial markets are not perfect, and must be regulated and supervised to increase the chances that expected results are achieved.

Regulation and supervision are aimed at i) ensuring soundness of financial institutions (called prudential regulation) and ii) ensuring that financial institutions conduct business in a fair and orderly manner in dealing with their customers (called market conduct). The later includes enforcement of consumer protection rules.

Banking in Ghana is regulated and supervised under what is referred to as the "silo" approach, or the "institutional" approach, or the "traditional" approach. That is to say, the bank regulator is responsible for regulating all aspects of banking (prudential regulation and market conduct) and does not regulate other financial service providers such as insurance, securities, or pensions. However, recent global developments within the financial services regulation space have leaned towards the so called twin peaks approach, under which all prudential regulation of all financial services providers fall under one regulator, and regulation of market conduct of all financial service providers are given to another regulator. Typically, a platform is created for the two regulators to meet regularly to compare and exchange notes.

In the Ghanaian situation, because of the "silo" regulatory environment, the central bank could only revoke the banking licenses of offending entities. Yet data presented here shows that many of the conglomerates include subsidiaries who offer other financial services.

Subsequent to the actions taken by the Bank of Ghana, the securities industry regulator has revoked licenses of more than 50 fund management firms found to be in contravention of the laws governing their businesses. The insurance industry regulator has not revoked any licenses, but has more than tripled the minimum capital required of insurance companies. The pension fund regulator has not yet taken any step publicly in this respect. Clearly, the "silo" approach to regulation is proving to be problematic. However, a number of the cases presented here included non-regulated entities, which muddies the waters further. It is probably time for Ghana to reconsider financial services regulatory architecture.

This study supports the recommendations of The Joint Forum (2011) and The Joint Forum on Financial Conglomerates (1999) discussed above. However, this paper recommends that, based on Ghana's recent experiences, banks should not be allowed to belong to conglomerate groups.

In the main, it would appear that the crisis that the Ghanaian banking sector has gone through has non-compliance with prudential regulations at its heart, once it appeared to some banks that they could get away with it. Thus, it makes sense to recommend that the central bank should be particularly vigilant with its risk-based supervision of conglomerates. 


\section{REFERENCES}

Akerlof, George A., and Paul Romer, (1993), "Looting: The Economic Underworld of Bankruptcy for Profit," Brookings Papers on Economic Activity, Microeconomics No. 2, 1-73.

Bank of Ghana, (2018), Corporate Governance Directive 2018: For Banks, Savings and Loans Companies, Finance Houses and Financial Holding Companies, December, Bank of Ghana.

Bertrand M., Mehta P., Mullainathan S., (2002), "Ferreting out tunneling," Quarterly Journal of Economics, 117, 121-148.

La Porta R., Lopez-de-Silanes F., Zamarripa G., (2003), "Related lending," Quarterly Journal of Economics, 118, 231-268.

Corporate Finance Institute, (2015). What is rent-seeking? Available at:

(https://corporatefinanceinstitute.com/re sources/knowledge/economics/rentseeking/

Fischer, P. (2005), Rent-Seeking, Institutions and Reforms in Africa: Theory and Empirical Evidence for Tanzania, University of Konstanz, Germany.

Graphic Online, (2017), December 12. Available at:

https://www.graphic.com.gh/business/bu siness-news/reasons-for-ut-capital-banksfailure.html.

Graphic Online, (2017), December 15 https://www.graphic.com.gh/business/bu siness-news/directors-of-collapsed-banksgranted-huge-loans-to-themselvesreport.html

Groupe Nduom website. Downloaded on October 10, 2019 at:

https://groupenduom.com/about_us.php

International Financial Reporting Standards, (2020), IAS 24.9 Related Party Disclosures, London. Available at:

https://www.ifrs.org/issued-standards / list-of-standards/ias-24-related-partydisclosures/

Joint Forum on Financial Conglomerates, (1999), Supervision of Financial Conglomerates, Bank for International Settlements. Available at: https://www.bis.org/publ/bcbs47 .pdf

Kang, J-K. and Stulz, R., (1997), "Is BankCentered Corporate Governance Worth it:
A Cross-Sectional Analysis of the Performance of Japanese Firms During the Asset Price Deflation," NBER Working Paper No. 6328.

Kawai, N., (2009), "Manufacturing - Shifting Gears," Japan Inc Magazine (March), Tokyo.

Khwaja, A. I. and Mian, A., (2005), "Do lenders favor politically connected firms? Rent provision in an emerging financial market," Quarterly Journal of Economics, 120, 1371-1411.

Khwaja, A. I. and Mian, A., (2011), "RentSeeking and Corruption in Financial Markets," Annual Review of Economics, 3, 579-600.

Lamoreaux, N. R., (1994), Insider Lending. Banks, Personal Connections, and Economic Development in Industrial New England, New York, N. Y, Cambridge University Press.

Media Ownership Montor, (2018), Who owns the media, Media Foundation for West Africa, Accra, October 2, 2018. Available at: https://ghana.mom-rsf.org/en/owners/ individual-owners/detail/owner/owner /show/dr-kwabena-duffuor/

Morck, R. and Nakamura, M., (1999), "Banks and Corporate Control in Japan," Journal of Finance, LIV 319-339.

Schwab, D. and Werker, E., (2018), "Are economic rents good for development? Evidence from the manufacturing sector,' World Development, 112, 33-45.

Sorkin A., (2009). Too Big to Fail: The Inside Story of How Wall Street and Washington Fought to Save the Financial System - and Themselves. New York: Viking

Tennant, D, (2013), Explaining Related Party Transactions in Commercial Banking: looted lending and information-based investments, Applied Financial Economics, 23, 1509-1530.

The Joint Forum, (2011), Principles of the supervision of financial conglomerates consultative document, Bank for International Settlements.

Tripathi, S., Fusaro, E., and Garg, A., (2019), "How conglomerates can do better in emerging markets," World View, (September). 